\title{
TRANSMISSION OF Campylobacter coli IN CHICKEN EMBRYOS
}

\author{
Daise Aparecida Rossi ${ }^{1}$, Belchiolina Beatriz Fonseca ${ }^{1,2^{*}}$, Roberta Torres de Melo ${ }^{1}$, Gutembergue da Silva Felipe ${ }^{1}$, Paulo \\ Lourenço da Silva ${ }^{1}$, Eliane Pereira Mendonça ${ }^{1}$, Ana Luzia Lauria Filgueiras ${ }^{3}$, Marcelo Emilio Beletti ${ }^{2}$
${ }^{1}$ Laboratório de Biotecnologia Animal Aplicada, Universidade Federal de Uberlândia, Uberlândia, MG, Brasil; ${ }^{2}$ Instituto de Ciências Biomédicas, Universidade Federal de Uberlândia, Uberlândia, MG, Brasil; ${ }^{3}$ Laboratório de Zoonoses Bacterianas, Instituto Oswaldo Cruz, Fundação Oswaldo Cruz, Rio de Janeiro, RJ, Brasil.

Submitted: December 08, 2010; Returned to authors for corrections: June 17, 2011; Approved: January 16, 2012.

\begin{abstract}
Campylobacter coli is an important species involved in human cases of enteritis, and chickens are carriers of the pathogen mainly in developing country. The current study aimed to evaluate the transmission of $C$. coli and its pathogenic effects in chicken embryos. Breeder hens were inoculated intra-esophageally with $C$. coli isolated from chickens, and their eggs and embryos were analyzed for the presence of bacteria using realtime PCR and plate culture. The viability of embryos was verified. In parallel, SPF eggs were inoculated with $C$. coli in the air sac; after incubation, the embryos were submitted to the same analysis as the embryos from breeder hens. In embryos and fertile eggs from breeder hens, the bacterium was only identified by molecular methods; in the SPF eggs, however, the bacterium was detected by both techniques. The results showed no relationship between embryo mortality and positivity for $C$. coli in the embryos from breeder hens. However, the presence of bacteria is a cause of precocious mortality for SPF embryos. This study revealed that although the vertical transmission is a possible event, the bacteria can not grow in embryonic field samples.
\end{abstract}

Key words: Campylobacter coli. Viability. Transmission. Breeder hens.

\section{INTRODUCTION}

Campylobacter spp., mainly $C$. jejuni and $C$. coli, are among the most commonly reported bacterial causes of human enteritis in industrialized countries (26). C. jejuni is the principal bacterial species found in developed countries; however, more recent studies have shown the importance of $C$. coli $(2,7,20)$. In developing countries, C. coli is also a common agent in human cases of enteritis, and chickens are important carriers of the pathogen.

Whether the transmission of Campylobacter spp. in chickens occurs mainly through of the horizontal via (19), the vertical route is a question that is still under discussion by the majority of authors and has not yet been fully answered. Moreover, this bacterium is considered nonpathogenic in birds, and the few reports available on the damage that it can cause to

*Corresponding Author. Mailing address: Instituto de Ciências Biomédicas, Universidade Federal de Uberlândia.; E-mail: bialucas@yahoo.com.br 
chicken embryos are limited to old work.

Due to the importance of $C$. coli and the scarce and old work on transmission and pathogenicity in chickens, this study aimed to evaluate the vertical transmission and pathogenic effects of $C$. coli in chicken embryos.

\section{MATERIALS AND METHODS}

\section{Inoculation of $C$. coli in breeder hens and analysis of eggs and chicken embryos}

Four breeder hens (Cobb Vantress) with 203 days old and confirmed to be negative for Campylobacter spp. by cloacal swab plate culture, were used in the experiments. These birds were kept until the age of 231 days in the experimental room at the Veterinary Hospital of the Universidade Federal de Uberlândia (UFU), MG, Brazil. They were inoculated intraesophageally every three days with $10^{3} \mathrm{CFU}$ of $C$. coli isolated from chicken feces. During 28 days, the birds were monitored for the presence of $C$. coli by cloacal swab plate culture. Eggs were collected twice daily (early morning and late afternoon) and immediately disinfected with $1 \%$ formalin solution spray.

The eggs were sorted into each experimental group based on the order of collection. The first egg was analyzed immediately (no incubation) and the following five eggs were incubated and removed for analysis depending on the order in which they were collected, for 24 hours, six days, 13 days, 17 days or 21 days. The cycle was then reinitiated repeatedly, with next egg being collected immediately and the following five analyzed after 24 hours, six days, 13 days, 17 days, or 21 days of incubation. Incubation took place in the experimental hatchery located at the Centro de Bioterismo e Experimentação Animal of the UFU (CBEA - UFU).

Inoculation of $C$. coli in the eggs of specific pathogen-free (SPF) poultry

One hundred SPF eggs were used: 50 for the test group and 50 as controls. Test group eggs were artificially inoculated with $0.1 \mathrm{~mL}$ of $0.85 \% \mathrm{NaCl}$ solution containing $10^{3} \mathrm{CFU}$ of $C$. coli isolated from birds. Bacteria were inoculated into the air sac without damaging the internal membrane, using sterile hypodermic needles $(0.3 \times 13 \mathrm{~mm})$. Control group eggs were inoculated in same place but with $0.1 \mathrm{~mL}$ of $0.85 \% \mathrm{NaCl}$ without bacteria.

The eggs were incubated similarly but in separate incubators for each experimental group (test and control), located at CBEA-UFU. Overall, six eggs were analyzed after 24 hours, ten eggs were analyzed after six days, 13 days and 17 days of incubation, and 14 eggs were analyzed after incubating to the day of hatching (21 days).

\section{Laboratory Diagnostic}

Samples were prepared in the Laboratório de Biotecnologia Animal Aplicada (LABIO). For SPF eggs incubated for 24 hours and eggs from intra esophageally inoculated breeder hens incubated for 24 hours and without incubation, $1 \mathrm{~mL}$ albumen and $1 \mathrm{~mL}$ yolk were collected and added to $9 \mathrm{~mL}$ of Bolton broth (Oxoid). For all others embryos (incubated for six days, 13 days, 17 days and 21 days), only the yolk was collected.

For intra-esophageally inoculated breeder hens, $1 \mathrm{~g}$ of meconium of hatched broilers and of embryos that died after 18 days of incubation was collected. In SPF embryos inoculated in the air sac, $1 \mathrm{~g}$ of jejunum and $1 \mathrm{~g}$ of cecum from hatched broilers and from embryos that died after 18 days of incubation were collected and placed in $9 \mathrm{~mL}$ of Bolton broth.

All the samples in Bolton broth were analyzed to identify and quantify $C$. coli using the BAX System Real-Time PCR assay (Dupon Qualicon); afterwards, the samples were incubated at $37^{\circ} \mathrm{C}$ during 24 hours in microaerophilic atmosphere (Probac microaerobac generator) for further culture.

Real-time PCR was performed according to the manufacturer's protocol (24). C. jejuni ATCC 33291 was also used as a positive control. 


\section{Campylobacter spp. culture}

After enrichment in Bolton broth, the samples (yolk, meconium, jejunum and cecum) were plated in CCDA agar with CCDA antibiotic supplement (Oxoid) and 5\% horse blood hemolysate and incubated at $37^{\circ} \mathrm{C}$ for 48 hours in a microaerophilic atmosphere (Probac microaerobic generator). C. jejuni ATCC 33291 was used as a positive control. Cloacal swabs from intra-esophagially inoculated breeder hens were plated directly without enrichment in Bolton broth. Characteristic colonies were confirmed as Campylobacter spp. by Gram staining and Campylobacter species were identified by multiplex PCR.

\section{Multiplex PCR}

Multiplex PCR was used to confirm the species of isolated colonies, as described by Harmon et al. (8). The heat-extracted DNA was amplified using the following primers (Invitrogen): Set I - flaA gene - C. jejuni and C. coli (460 bp) pg 3 and pg 50; and Set II - C. jejuni (160 bp) C1 and C4, described by Gillespie et al. (7). PCR amplification was carried out with $20 \mathrm{ng}$ of DNA and the reagents (Invitrogen), as previously described (25). The PCR amplification was performed in a Thermal Controller (PTC 150 - MJ Research, Inc.) with cycles as previously described by Harmon et al. (8). PCR reaction products were separated by electrophoresis in $1.5 \%$ agarose gel stained with ethidium bromide, with a $100 \mathrm{bp}$ ladder as molecular weight marker (Invitrogen); the gels were visualized under UV light, in a transilluminator (Chemical Company T102 SIGMA).

\section{Statistical analysis}

Descriptive statistics were used to compare the results of real-time PCR and microbiological analysis and the number of viable embryos or chicks. The kappa coefficient $(p<0.05)$ was used to compare the results obtained in conventional culture plate analysis and those obtained by real-time PCR. The Biostat 5.0 program was used for these analyses (1).

\section{Approval of an appropriate ethics committee}

Chicken embryos and hatched broilers were sacrificed according Comitê de Ética na Utilização de Animais (CEUA) da Universidade Federal de Uberlândia, number 057/09 and number 323/09.

\section{RESULTS AND DISCUSSION}

Cloacal swabs of breeder hens artificially contaminated (intra-esophageal route) with $C$. coli

The positivity of Campylobacter spp. in cloacal swabs from breeder hens inoculated by the intra-esophageal route was of $54.5 \%, 36.3 \%, 54.5 \%$ and $45.4 \%$ in the breeder hens one, two, three and four, respectively, during the 11 days that were monitored. There was no pattern to the excretion of Campylobacter in breeder hens' cloacal swabs because in different days pos-inoculation there were Campylobacter spp negative animals. These results are in disagreement with those of Mbata (14), who found that the elimination of Campylobacter is persistent.

\section{Fresh eggs, embryos and chicks of breeder hens artificially} contaminated (intra-esophageal route) with $C$. coli

C. coli was absent from embryos incubated for 24 hours, 13 days and 17 days, but it was found in fresh eggs, embryos incubated for six days and newly hatched chicks (Table 1).

The real-time PCR showed that 25.0\% (2/8) of fresh eggs contained $C$. coli. The bacteria was found only in the albumen of eggs with count of $1.9 \times 10^{4} \mathrm{CFU} / \mathrm{g}$ and $8.2 \times 10^{5} \mathrm{CFU} / \mathrm{g}$. $C$. coli was not isolated by plate culture method.

Among chicken embryos analyzed with six days of incubation, $12.5 \%(2 / 16)$ were positive for C. coli; of these, only one died, after five days of incubation. In chicken embryos or newly hatched eggs analyzed with 21 days of incubation, a $20.0 \%(2 / 10)$ positivity of $C$. coli was detected by real-time PCR. The bacteria were found in the yolk in one case, and in the meconium in the other case (Table 1). 
However, the bacterium was not isolated by the method of plate culture in the periods analyzed.

There was not relationship between embryonic mortality and $C$. coli positivity in chicken embryos from breeder hens inoculated intra-esophageally.

In this study, bacteria in the yolk of intra-esophageally inoculated hens were detected only by real-time PCR. C. coli was absent from embryos incubated for 24 hours, 13 days or 17 days, but was present in fresh eggs, embryos incubated for six days and newly hatched chicks (Table 1). The concentrations of the PCR samples ranged from $1.9 \times 10^{4} \mathrm{CFU} / \mathrm{g}$ to $1.7 \times 10^{6}$ $\mathrm{CFU} / \mathrm{g}$, values greater than inoculated concentration of bacterium $\left(1 \times 10^{3} \mathrm{CFU}\right)$. Thus, these results indicate that replication of the bacteria occurred after inoculation (Table 1). Despite the samples had been negative by culture, it is important emphasize the existence of forms of bacterium called viable but non-cultivable form (VNC), which is not recoverable in plate culture.

Table 1. Viability and presence of Campylobacter in six-day-old chicken embryos and chicken embryos or newly hatched in 21 day-old incubation from hens inoculated by intra-esophageal with C. coli.

\begin{tabular}{|c|c|c|c|c|c|c|}
\hline \multirow{3}{*}{$\begin{array}{c}\text { Age of } \\
\text { incubation }\end{array}$} & \multirow{3}{*}{ Identification } & \multirow{3}{*}{ Sample } & \multicolumn{4}{|c|}{ Protocol analysis } \\
\hline & & & \multicolumn{3}{|c|}{ real time $\mathrm{PCR}$} & \multirow{2}{*}{ Viability } \\
\hline & & & Result & Specie & CFU/g & \\
\hline \multirow{5}{*}{$\begin{array}{l}\text { six-day-old } \\
\text { chicken } \\
\text { embryos }\end{array}$} & $8^{\prime \prime}, 9^{\prime}, 10^{\prime}, 11^{\prime}, 12^{\prime} 13^{\prime}, 14^{\prime}, 16^{\prime}, 17^{\prime}, 18^{\prime}, 19^{\prime}, 20^{\prime *}$ & yolk & $\mathrm{N}$ & - & - & Viable \\
\hline & 15 & yolk & $\mathrm{P}$ & C. coli & $1.7 \times 10^{6}$ & Viable \\
\hline & $21^{\prime}$ & yolk & $\mathrm{N}$ & - & - & EM 4 days \\
\hline & $22^{\prime}$ & yolk & $\mathrm{N}$ & - & - & EM 2 days \\
\hline & 23 & yolk & $\mathrm{P}$ & C. coli & $4.4 \times 10^{4}$ & EM 5 days \\
\hline & $24^{\prime}, 25^{\prime}, 26^{\prime}, 29^{\prime} *$ & yolk & $\mathrm{N}$ & -- & -- & \multirow{2}{*}{ Viable } \\
\hline & $24^{\prime}, 25^{\prime}, 26^{\prime}, 29^{\prime} *$ & meconium & $\mathrm{N}$ & -- & -- & \\
\hline & 27 & yolk & $\mathrm{P}$ & C. coli & $2.8 \times 10^{4}$ & \multirow{2}{*}{ Viable } \\
\hline chicken & 27 & meconium & $\mathrm{N}$ & -- & -- & \\
\hline embryos or & $28^{\prime}$ & yolk & $\mathrm{N}$ & -- & -- & \multirow{2}{*}{ EM 21 days } \\
\hline newly hatched & 28 & meconium & $\mathrm{N}$ & -- & -- & \\
\hline in 21 & $30^{\prime}$ & yolk & $\mathrm{N}$ & -- & -- & EM 4 days \\
\hline day-old & $31^{\prime}$ & meconium & $\mathrm{N}$ & -- & -- & \multirow{2}{*}{ EM 19 days } \\
\hline \multirow[t]{4}{*}{ incubation } & 31, & yolk & $\mathrm{N}$ & -- & -- & \\
\hline & $32^{\prime}$ & yolk & $\mathrm{N}$ & -- & -- & EM 3 days \\
\hline & $33^{\prime}$ & yolk & $\mathrm{N}$ & -- & -- & \multirow{2}{*}{ Viable } \\
\hline & $33^{\prime}$ & meconium & $\mathrm{P}$ & C. coli & $4.7 \times 10^{4}$ & \\
\hline
\end{tabular}

$\overline{\mathrm{N}: \text { Negative; P: Positive; *Analysis individual with similar results; EM: embryo mortality }}$

Depending on the severity and type of stress, the microorganisms present survival strategies and thus, can enter the state VNC, where the cells retain metabolic activity, but are not cultivated by conventional methods available. According to Murphy et al. (16), state VNC is a major concern for public health agencies, since these cells can return to normal vegetative metabolism. This process is called resuscitation, thus increasing the potential risk of infection caused by food for consumption.
The presence of bacterium although real-time PCR over $10^{3} \mathrm{CFU} / \mathrm{g}$ shows that transovarian transmission is possible and that the microorganism can penetrate the egg shell pores and survive during the incubation period. This can be explained by the size of the egg shell pores $(11 \mu \mathrm{m}$ to $12 \mu \mathrm{m})(21)$, although the albumen is not an appropriate environment for growth (3, 11). Fonseca et al. (6) found that Campylobacter is not viable in infertile eggs inoculated by air sac but albumen doesn't avoid the bacterial growth when inoculated the bacterium in 
the albumen.

There are no reports in the literature regarding the use of PCR and direct plate culture for C. coli. For C. jejuni, however, Hiett et al. (9) found results similar to ours, with $70.0 \%$ of eggs positive by direct PCR but negative by plate culture. Fonseca et al. (5) found $80.0 \%$ positivity in the meconium of broilers from breeder hens naturally contaminated with Campylobacter using PCR, but not by plate culture.

Other authors $(12,27)$ have found embryonic mortality in birds artificially inoculated with $C$. jejuni but there are no such reports for birds naturally contaminated with $C$. coli or $C$. jejuni.

C. coli in the yolk of embryos or in the meconium of broilers from breeder hens inoculated intra-esophageally with C. coli did not kill the embryos $(\mathrm{p}>0.05)$. There were 17 viable embryos and negative in real-time PCR and 1 embryos precocity died, which was positive in real-time PCR. Most researchers claim that vertical transmission is not possible, but older works mention that, under experimental conditions, the bacteria caused embryonic mortality when inoculated in eggs $(12,13,27)$.

Fresh eggs, embryos and chicks from SPF eggs inoculated

\section{with $C$. coli in the air sac}

Among eggs incubated for 24 hours, 83.3\% (5/6) in the test group were positive for $C$. coli in the albumen or yolk (Table 2). The control group samples were negative.

In embryos incubated for six, 13 and 17 days, $C$. coli was found with at least one of the techniques used in 50.0\% $(5 / 10)$, $100.0 \%(10 / 10)$ and $80.0 \%(8 / 10)$ of samples, respectively (Table 3).

All chicken embryos in the control group were negative with both detection methods. Of the ten eggs assigned to six days of incubation, six were alive, one was infertile, two died within three days and one died within two days. Of the ten embryos assigned to 13 days of incubation, six were alive, one was infertile, two died within two days and one died within three days. Of the eggs incubated for 17 days, six were alive, two died within four days, one died within three days and another died within two days.

Among eggs incubated until the day of hatching (21 days of incubation), Campylobacter sp. was not found in the jejunum, cecum or yolk in the test group. C. coli was present only in embryos with early mortality (less than six days of incubation), with a prevalence of $35.7 \%(5 / 14)$ in this subgroup (Table 4).

Table 2. Campylobacter sp. in albumen and yolk from SPF eggs air chamber contaminated with C.coli after 24 hours.

\begin{tabular}{|c|c|c|c|c|c|}
\hline \multirow{3}{*}{ Egg } & \multirow{3}{*}{ Sample } & \multicolumn{4}{|c|}{ Protocol analysis } \\
\hline & & \multicolumn{3}{|c|}{ Real time PCR } & \multirow{2}{*}{$\begin{array}{c}\text { Microbiology } \\
\left(\mathrm{mpcr}^{2}\right)\end{array}$} \\
\hline & & Result & Specie & $\mathrm{CFU} / \mathrm{g}$ & \\
\hline 1 & Albumen & $\mathrm{N}$ & -- & -- & $\mathrm{N}$ \\
\hline 1 & yolk & $\mathrm{N}$ & -- & -- & $\mathrm{N}$ \\
\hline 2 & Albumen & $\mathrm{N}$ & -- & -- & $\mathrm{N}$ \\
\hline 2 & yolk & $\mathrm{P}$ & C. coli & $9.6 \times 10^{6}$ & $\mathrm{P}($ C.coli $)$ \\
\hline 3 & Albumen & $\mathrm{P}$ & C. coli & $1.0 \times 10^{4}$ & $\mathrm{P}($ C.coli $)$ \\
\hline 3 & yolk & $\mathrm{P}$ & C. coli & $3.9 \times 10^{7}$ & $\mathrm{P}($ C.coli $)$ \\
\hline 4 & Albumen & $\mathrm{P}$ & C. coli & $5.2 \times 10^{4}$ & $\mathrm{~N}$ \\
\hline 4 & yolk & $\mathrm{P}$ & C. coli & $7.9 \times 10^{6}$ & $\mathrm{P}($ C.coli $)$ \\
\hline 5 & Albumen & $\mathrm{P}$ & C. coli & $1.9 \times 10^{4}$ & $\mathrm{P}($ C.coli $)$ \\
\hline 5 & yolk & $\mathrm{N}$ & -- & -- & $\mathrm{N}$ \\
\hline 6 & Albumen & $\mathrm{P}$ & C. coli & $2.4 \times 10^{7}$ & $\mathrm{P}($ C.coli $)$ \\
\hline 6 & yolk & $\mathrm{P}$ & C. coli & $7.9 \times 10^{6}$ & $\mathrm{~N}$ \\
\hline
\end{tabular}


Table 3. Viability and presence of Campylobacter in six-day-old, 13-day-old and 17-day-old chicken embryos from SPF eggs inoculated with C. coli.

\begin{tabular}{|c|c|c|c|c|c|c|}
\hline \multirow{3}{*}{$\begin{array}{c}\text { Age of } \\
\text { incubation }\end{array}$} & \multirow{3}{*}{ Identification } & \multicolumn{5}{|c|}{ Protocol analysis } \\
\hline & & \multicolumn{3}{|c|}{ Real time PCR } & \multirow{2}{*}{$\begin{array}{c}\text { Microbiology } \\
\left(\mathrm{mpcr}^{2}\right)\end{array}$} & \multirow[t]{2}{*}{ Viability } \\
\hline & & Result & Specie & CFU/g & & \\
\hline \multirow{7}{*}{$\begin{array}{l}\text { Six day old } \\
\text { chicken } \\
\text { embrios }\end{array}$} & 7 & $\mathrm{P}$ & C. coli & $1.8 \times 10^{7}$ & $\mathrm{P}($ C.coli $)$ & EM 5 days \\
\hline & 8 & $\mathrm{P}$ & C. coli & $3.4 \times 10^{4}$ & $\mathrm{P}($ C.coli $)$ & Viable \\
\hline & $9,10,11,12^{*}$ & $\mathrm{~N}$ & - & - & $\mathrm{N}$ & Viable \\
\hline & 13 & $\mathrm{P}$ & C. coli & $1.8 \times 10^{7}$ & $\mathrm{P}($ C.coli $)$ & Infertile \\
\hline & 14 & $P$ & C. coli & $1.4 \times 10^{8}$ & $\mathrm{P}($ C.coli $)$ & Viable \\
\hline & 15 & $\mathrm{P}$ & C. coli & $9.6 \times 10^{5}$ & $\mathrm{P}($ C.coli $)$ & EM 2 days \\
\hline & 16 & $\mathrm{~N}$ & -- & -- & $\mathrm{N}$ & EM 3 days \\
\hline \multirow{10}{*}{$\begin{array}{l}13 \text { day old } \\
\text { chicken } \\
\text { embryos }\end{array}$} & 17 & $\mathrm{P}$ & C. coli & $3.0 \times 10^{7}$ & $\mathrm{P}($ C.coli $)$ & EM 2 days \\
\hline & 18 & $\mathrm{P}$ & C. coli & $8.9 \times 10^{6}$ & $\mathrm{P}($ C.coli $)$ & EM 2 days \\
\hline & 19 & $\mathrm{P}$ & C. coli & $4.6 \times 10^{6}$ & $\mathrm{P}($ C.coli $)$ & EM 2 days \\
\hline & 20 & $\mathrm{P}$ & C. coli & $3.2 \times 10^{6}$ & $\mathrm{P}($ C.coli $)$ & Infertile \\
\hline & 21 & $\mathrm{P}$ & C. coli & $1.1 \times 10^{6}$ & $\mathrm{P}($ C.coli $)$ & EM 3 days \\
\hline & 22 & $\mathrm{P}$ & C. coli & $2.4 \times 10^{6}$ & $\mathrm{P}($ C.coli $)$ & EM 3 days \\
\hline & 23 & $\mathrm{P}$ & C. coli & $2.0 \times 10^{7}$ & $\mathrm{P}($ C.coli $)$ & EM 2 days \\
\hline & 24 & $\mathrm{P}$ & C. coli & $2.0 \times 10^{7}$ & $\mathrm{P}($ C.coli $)$ & EM 2 days \\
\hline & 25 & $\mathrm{P}$ & C. coli & $3.9 \times 10^{5}$ & $\mathrm{~N}$ & Viable \\
\hline & 26 & $\mathrm{P}$ & C. coli & $1.1 \times 10^{6}$ & $\mathrm{P}($ C.coli $)$ & Viable \\
\hline \multirow{10}{*}{$\begin{array}{l}17 \text { day old } \\
\text { chicken } \\
\text { embryos }\end{array}$} & 27 & $\mathrm{P}$ & C. coli & $<1.0 \times 10^{4}$ & $\mathrm{P}($ C.coli $)$ & EM 2 days \\
\hline & 28 & $\mathrm{P}$ & C. coli & $5.5 \times 10^{4}$ & $\mathrm{P}($ C.coli $)$ & EM 1 day \\
\hline & 29 & $\mathrm{P}$ & C. coli & $6.8 \times 10^{6}$ & $\mathrm{P}($ C.coli $)$ & EM 4 days \\
\hline & 30 & $\mathrm{~N}$ & -- & -- & $\mathrm{N}$ & Viable \\
\hline & 31 & $\mathrm{~N}$ & -- & -- & $\mathrm{N}$ & EM 2 days \\
\hline & 32 & $\mathrm{P}$ & C. coli & $1.5 \times 10^{7}$ & $\mathrm{P}($ C.coli $)$ & EM 3 days \\
\hline & 33 & $\mathrm{P}$ & C. coli & $2.0 \times 10^{6}$ & $\mathrm{P}($ C.coli $)$ & EM 3 days \\
\hline & 34 & $\mathrm{P}$ & C. coli & $3.8 \times 10^{6}$ & $\mathrm{P}($ C.coli $)$ & EM 3 days \\
\hline & 35 & $\mathrm{P}$ & C. coli & $9.7 \times 10^{5}$ & $\mathrm{P}($ C.coli $)$ & EM 2 days \\
\hline & 36 & $\mathrm{P}$ & C. coli & $8.6 \times 10^{6}$ & $\mathrm{P}($ C.coli $)$ & EM 2 days \\
\hline
\end{tabular}

${ }^{1}$ plate culture; ${ }^{2}$ multiplex PCR; N: Negative; P: Positive; ${ }^{*}$ Analysis individual with similar results; EM: embryo mortality

Table 4. Viability and presence of Campylobacter in embryos or chicks hatched on the day of hatching from SPF eggs inoculated with $C$. coli.

\begin{tabular}{|c|c|c|c|c|c|c|}
\hline \multirow{3}{*}{ Identification } & \multirow{3}{*}{ Sample } & \multicolumn{4}{|c|}{ Protocol analysis } & \multirow{3}{*}{ Viability } \\
\hline & & \multicolumn{3}{|c|}{$\begin{array}{l}\text { PCR Real time } \\
\end{array}$} & \multirow{2}{*}{$\begin{array}{c}\text { Microbiology } \\
\left(\mathrm{mpcr}^{2}\right)\end{array}$} & \\
\hline & & Result & Specie & CFU/g & & \\
\hline \multirow{6}{*}{$38,39,46,40,49,50^{*}$} & Yolk & $\mathrm{N}$ & -- & -- & $\mathrm{N}$ & \multirow{3}{*}{ EM 20 days } \\
\hline & Jejunum & $\mathrm{N}$ & -- & -- & $\mathrm{N}$ & \\
\hline & Cecum & $\mathrm{N}$ & -- & -- & $\mathrm{N}$ & \\
\hline & Yolk & $\mathrm{N}$ & -- & -- & $\mathrm{N}$ & \multirow{3}{*}{ Viable } \\
\hline & Jejunum & $\mathrm{N}$ & -- & -- & $\mathrm{N}$ & \\
\hline & Cecum & $\mathrm{N}$ & -- & -- & $\mathrm{N}$ & \\
\hline \multirow[t]{2}{*}{41} & Yolk & $\mathrm{N}$ & - & - & $\mathrm{N}$ & EM 3 days \\
\hline & Yolk & $\mathrm{N}$ & -- & -- & $\mathrm{N}$ & \multirow{3}{*}{ EM 20 days } \\
\hline \multirow[t]{2}{*}{42} & Jejunum & $\mathrm{N}$ & -- & -- & $\mathrm{N}$ & \\
\hline & Cecum & $\mathrm{N}$ & -- & -- & $\mathrm{N}$ & \\
\hline 43 & Yolk & $\mathrm{P}$ & C. coli & $3.3 \times 10^{6}$ & $\mathrm{P}($ C.coli $)$ & EM 2 days \\
\hline 44 & Yolk & $\mathrm{P}$ & C. coli & $1.2 \times 10^{6}$ & $\mathrm{P}($ C.coli $)$ & EM 2 days \\
\hline 45 & Yolk & $\mathrm{P}$ & C. coli & $5.3 \times 10^{6}$ & $\mathrm{P}($ C.coli $)$ & EM 3 days \\
\hline 47 & Yolk & $\mathrm{P}$ & C. coli & $2.5 \times 10^{7}$ & $\mathrm{P}($ C.coli $)$ & EM 6 days \\
\hline 48 & Yolk & $\mathrm{P}$ & C. coli & $1.1 \times 10^{7}$ & $\mathrm{~N}$ & EM 2 days \\
\hline
\end{tabular}


Of the 14 eggs incubated for 21 days in the control group, six chicks hatched, three were alive but remained inside the partially broken egg shell, one was infertile, one died within one day, one died within four days, one died within six days and another died within seven days.

The rate of $C$. coli positivity was high with real-time PCR and traditional plate culture for SPF eggs inoculated in the air sac. The concentrations of bacteria in the albumen and yolk ranged from $1.0 \times 10^{4} \mathrm{CFU} / \mathrm{g}$ to $3.9 \times 10^{7} \mathrm{CFU} / \mathrm{g}$ indicating that replication occurred inside the eggs.

Unlike the embryos from breeder hens inoculated intraesophageally with $C$. coli, SPF embryos inoculated in the air sac had higher embryonic mortality in the test group than in the control group. Therefore, embryonic mortality was associated with the presence of bacteria in the test group.

In embryos from breeder hens contaminated intraesophagially with $C$. coli, only real-time PCR yielded positive results. However, for SPF embryos, there was an excellent replicability between real-time PCR and culture plate methods, based on the kappa coefficient $(\mathrm{K}=0.8921, \mathrm{p}<0.0001)$.

The kappa test comparing the results of plate culture and real-time PCR as well as the presence of the positive control $C$. jejuni ATCC 33291 shows that the techniques used in this study did not present problem on isolation of the bacterium viable cultivable. However, it is important consider the VNC forms, which are not recoverable in plate culture.

Embryonic mortality occurred early in SPF embryos inoculated in the air sac (less than seven days of hatching). Early mortality is probably due to the embryo's active immunity, because embryos incubated for 14 days acquire the functional capacity to detect the entry of an antigen (28).

Research on embryonic mortality and vertical transmission of $C$. coli is unusual. However, there have been some studies with $C$. jejuni. The embryonic mortality in $C$. coli contaminated eggs in this study is comparable to previously published results $(12,13)$, in which the inoculation of some strains of $C$. jejuni in the corioalantoid membrane was found to be lethal to embryos. Zaki e Reda (27) found $0.7 \%$ early mortality in chicken embryos positive for $C$. jejuni after inoculation; late embryonic mortality was $1.8 \%$ and $2.1 \%$ of chicks broke the shell but did not fully hatch.

Vertical transmission is commonly discussed as an epidemiologically important route of infection in birds. Most authors mention that this is not the main route of transmission $(2,10)$ but Pearson et al. (18), using epidemiological analysis, and Cox et al. (4), by comparing the genetic patterns of bacteria isolated in breeding and their progeny, agreed that vertical transmission is an important route of Campylobacter transmission in birds. Based on this study, we can affirm that vertical transmission is a possible route of infection.

In other findings from Melo et al. (15), C. jejuni quickly penetrated egg shell pores and reached the yolk of eggs from fertile SPF when the egg matrix was in contact with woodshavings contaminated with $C$. jejuni.

The high rates of embryonic mortality in Campylobacterpositive SPF eggs along with the lower mortality in Campylobacter-positive eggs from intra-esophagially inoculated breeder hens leads to speculation that some factor prevents the survival of $C$. coli in breeder hen eggs.

The non-viability of $C$. coli in the eggs of inoculated breeder hens may be associated with the birds' immunology. Sahin et al. (19) found high levels of antibodies against Campylobacter in broilers in the first and second week of life, but the antibodies declined or even disappeared in the third and fourth week. The absence of antibodies in the third week coincides with peaks of Campylobacter infection in many chicken farms $(17,22,28)$, showing that maternal immunity is an important barrier to infection. In this work however, we did not use immunological tools that could support this hypothesis.

Another possible explanation is that the bacteria adopt some sort of protection mechanism until the maternal antibodies disappear, after which they become viable and replicate, similarly to what occurs in the laboratory (23). Under extreme temperature and $\mathrm{pH}$ conditions, the bacteria adopt 
forms that are VNC.

\section{CONCLUSION}

Campylobcater coli are pathogenic to SPF chicken embryos and causes high early embryonic mortality. However, in embryos from breeder hens, vertical transmission is a possible route of infection but the bacterium would be either VNC form or nonviable in plate culture and the bacterium isn't a pathogenic in chicken embryos.

\section{ACKNOWLEDGEMENTS}

This study was financed by the "Fundação de Amparo a Pesquisa de Minas Gerais" (FAPEMIG) (Minas Gerais Research Support Foundation) and "Conselho Nacional de Desenvolvimento Científico e Tecnológico" (CNPq) (Federal Brazilian Research Support Foundation).

\section{REFERENCES}

1. Ayres, M.; Ayres-Junior, M.; Ayres, D.L.; Santos, A.A.S. (2007) BioEstat: Aplicações estatísticas nas áreas das ciências biomédicas. Belém: Sociedade Civil Mamirauá, 324p.

2. Bull, S.A.; Allen, V.M.; Domingue, G.; Jorgensen, F.; Frost, J.A.; Ure, R.; Whyte, R.; Tinker, D.; Corry, J.E.L.; Gillard-King, J.; Humphrey, T.J. (2006). Sources of Campylobacter spp. colonizing housed broiler flocks during rearing. Appl. Environ. Microbiol. 72 (1), 645-65.

3. Cogan, T.A.; Domingue, G.; Lappin-Scott, H.M.; Benson, C.E.; Woodward, M.J.; Humphrey, T.J. (2001). Growth of Salmonella enteritidis in artificially contaminated eggs: the effects of inoculum size and suspending media. Int. J. Food Microbiol. 70 (1-20), 131-141.

4. Cox, N.A.; Stern, N.J.; Hiett, K.L.; Berrang, M.E. (2002). Identification of a new source of Campylobacter contamination in poultry: Transmission from breeder hens to broiler chickens. Avian Dis. 46 (3), 535-541.

5. Fonseca, B.B.; Soncini, R.A.; Frezza, A.L.C.; Rossi, D.A. (2007) Campylobacter sp em mecônio de pintainhos e em cloaca de reprodutoras. Biosci. J. 23 (3), 128-132.

6. Fonseca, B.B.; Rossi, D.A.; Paula, A.T. Passagem e viabilidade de $C$. jejuni em ovos comerciais. In: Simpósio IAFP América Latina,
Campinas, 2008.

7. Gillespie, I.A.; O’brien. S.J.; Frost, J.A.; Adak, G.K.; Horby, P.; Swan, A.V.; Painter, M.J.; Neal, K.R. (2002). A Case-Case Comparison of Campylobacter coli and Campylobacter jejuni Infection: A Tool for Generating Hypotheses. Emerg. Infect. Dis. 8 (9), 937-942.

8. Harmon, K.M.; Ramsom, G.M.; Wesley, I.V. (1997). Differentiation of C. jejuni and C.coli by polymerase chain reaction. Mol. Cel.l Probes. 11 (3), 195-200.

9. Hiett, K.L.; Cox, N.A.; Stern, N. (2002). Direct Polymerase Cahin Reaction Detection of Campylobacter spp. in Poultry Hatchery Samples. Avian Dis. 46 (1), 219-223.

10. Jacobs-Reitsma, W.F. (1995). Campylobacter Bacteria in Breeder Flocks. Avian Dis. 39 (2), 355-359.

11. Jay, J.M. (2000). Modern food microbiology. Maryland: SPRINGER, $767 \mathrm{p}$.

12. King, V.; Bavetsia, A.; Bumstead, N. (1993). Effect of host lineage on the virulence of Campylobacter jejuni in the chicken embryo model. FEMS Microbiol. Lett. 106 (3), 271-274.

13. Lam, K.M.; Damassa, A.J.; Morishita, T.Y.; Shivaprasad, H.L.; Bickford, A.A. (1992). Pathogenicity of Campylobacter jejuni for Turkeys and Chickens. Avian Dis. 36, 359-363.

14. Mbata, T.I. (2005). Poultry meat pathogens and its control. Internet J. Food Safety. 7, 20-28.

15. Melo, R.T.; Silva, D.S.; Fonseca, B.B. Penetração de C. jejuni em ovos comerciais e férteis. In: CONFERÊNCIA APINCO DE CIÊNCIA E TECNOLOGIA AVÍCOLAS - PRÊMIO LAMAS DE PESQUISA AVÍCOLA. Porto Alegre: FACTA. 2009.

16. Murphy, C.; Carroll, C.; Jordan, K..N. (2003). Induction of adaptive tolerance response in the foodborne pathogen, Campylobacter jejuni. FEMS Microbil. Lett. 223, 89-93.

17. Newell, I.; Wagenaar, J.A. Poultry infections and their control at the farm level. In: NACHAMKIN, I.; BLASER, M.J. (Ed). Campylobacter. Washington: AMERICAN SOCIETY FOR MICROBIOLOGY, 2000. 121-138.

18. Pearson, A.D.; Greenwood, M.H.; Feltham, R.K.A.; Healing, T.D.; Donaldson, J.; Jones, D.M.; Colwell, R.R. (1996). Microbial Ecology of C. jejuni in a United Kingdom Chicken Supply Chain: Intermittent Common Source, Vertical Transmission, and Amplification by Flock Propagation. Appl. Environ. Microbiol. 62 (12), 4614-20.

19. Sahin, O.; Zhang, Q.; Meitzler, J.C.; Harr, B.S.; Morishita, T.Y.; Mohan, R. (2001). Prevalence, Antigenic Specificity, and Bactericidal Activity of Poultry Anti Campylobacter Maternal Antibodies. Appl. Environ. Microbiol. 67 (9), 3951-3957.

20. Sails, A.D., Swaminathan, B., Fields, P.I. (2003). Utility of multilocus sequence typing as an epidemiological tool for investigation of outbreaks of gastroenteritis caused by Campylobacter jejuni. J. Clin. Microbiol. 41 
(10), 4733-4739.

21. Sesti, L.A.; Ito, N.M.K. Enfermidades do Sistema Reprodutor. In: BERCHIERI Jr, A.; MACARI, M. (Ed). Doenças das Aves. Campinas: FACTA, 2000. p.81-128.

22. Stern, N.J. (1992). Reservoirs of C. jejuni and approaches for intervention in poultry. In: NACHAMKIN, I.; BLASER, M.J.; TOMPKINS, L.S. (Ed). Campylobacter jejuni: current status and future trends. Washington: AMERICAN SOCIETY FOR MICROBIOLOGY, p.49-60.

23. Trachoo, N.; Frank, J.F.; Stern, N.J. (2002). Survival of Campylobacter jejuni biofilms isolated from chicken houses. J. Food Prot. 65 (7), 11101116.

24. User'S Guide. BAX®System. PCR assay with automated detection for bacterial screening. Du Pont Qualicon, Wilmington, DE. 2007.

25. Vilardo, M.C.B.; Thomé, J.D.S.; Esteves, W.T.C.; Filgueiras, A.L.L.; Oliveira, S.S. (2006). Application of biochemical and polymerase chain reaction assays for identification of Campylobacter isolates from nonhuman primates. Mem. Inst. Oswaldo Cruz. 101 (5), 499-501.

26. World Health Organization (WHO). The increasing incidence of human campylobacteriosis. Copenhagen: DENMARK, 2000. p.21-25.

27. Zaki, M.M.; Reda, W.W. (1995). Campylobacter in poultry. Vet. Med. J. 43 (1), 71-76.

28. Zhang, Y.; Sharma, J.M. (2003). Immunological tolerance in chickens hatiching from eggs injected with cell-associated herpesvirus of turkey (HVT). Dev. Comp. Immunol. 27 (5), 431-438. 